\title{
Perception and Communication Issues Between Croatia and the European Union - From Croatian Independence in 1991 to EU Accession in 2013
}

Preliminary communication _ UDK 159.937:316.77(4:497.5)"1991/2013" _ Received on 18 January 2016

Božo Skoko

Faculty of Political Science, University of Zagreb, Croatia. Email: bozo.skoko@mpr.hr

\section{Abstract}

In 2013, Croatia became the 28th member of the European Union. However, the road to full membership was quite lengthy and marked by numerous ups and downs in mutual relations and accession negotiations. The paper deals with the communication aspects of the relationship between Croatia and the European Union, that is, their mutual perception in the period from Croatia's independence in 1991 to full membership 22 years later. The paper demonstrates how the mutual relations and perceptions were, for years, burdened by numerous stereotypes from the past, the consequences of Yugoslavian propaganda, unrealistic expectations, the behavior of European institutions during the breakup of Yugoslavia and traumas from the Homeland Defense War, as well as insufficient and unsatisfactory communication between European and Croatian institutions. All this resulted in the continuous decline in confidence in the EU among Croatian citizens on the one hand, and the delay in membership negotiations on the other. This paper brings together in one place all relevant past findings, places them within the context of interrelations between Croatia and the European Union and brings original research on the perception of the European Union in Croatia just prior to full membership. Furthermore, the paper analyses the historical context of the mutual relations between Croatia and the EU.

Keywords: image, Croatia, European Union, perceptions, communications 


\section{Introduction and theoretical framework}

It is a well-known fact that, in international relations, image plays a significant role, and this is directly reflected in the political and economic position of the country or other subjects in international relations, as well as others toward them. As such, it can play a significant role when making political decisions, investments, buying products, tourist visits, acceptance of various cultural influences and trends etc. This is confirmed by numerous authors, such as Simon Anholt (2007), Keith Dinnie (2008), Eugene D. Jaffe and Israel D. Nebenzahl (2006), Michael Kunczik (1997), Ingrid M. Martin and Sevgin Eroglu (1993), Nicolas Papadopoulos and Louise A. Heslop (1993) and others. Two theoretical concepts support this - the country-of-origin effect and soft power (Nye, 2003). Research by Papadopoulos and Heslop on the country-of-origin effect was published in 1993. In 1994, Robert A. Peterson and Alain J. P. Jolibert found in academic journals 184 articles dealing with the country-of-origin effect (see Kotler, Gertner, 2005, p. 43). The findings kept confirming the fact that consumers had been using the country-of-origin information as a quality indicator. It was observed how simple manipulations with such information or with the "made in" designation influenced people's attitudes, even when they could see, feel, try and taste the physical products themselves (Nagashima, 1970; Terpstra, 1988; Chao, 1989; Hong, Wyer, 1990; Wall et al., 1991; Johansson et al., 1994; Jaffe, Martinez, 1995; Liefeld et al., 1996; Li et al., 1997; Papadopulos, Heslop, 2000). Joseph Nye (1990, 2002,2004 ) was the first one to analyze the soft power phenomenon when he wrote about U.S. world dominance. In Nye's opinion, that dominance was based not only on military and economic power, but also on the so-called third dimension - the one he named soft power. Nye defines soft power as the capability of convincing others to want what you want. "A country may obtain the outcomes it wants in world politics because other countries - admiring its values, emulating its example, aspiring to its level of prosperity and openness - want to follow it" (Nye, 2003, p. 8). Thus, both concepts clearly highlight the strength of image in international relations. Philip Kotler and David Gertner (2005, p. 43) hold that images can be long-lasting and hard to change, but they also add that they can be evaluated and measured, and that marketing experts can manage and influence them. It seems logical when we know that images are created artificially and that people act on the basis of what they believe is the truth, not on the basis of real truth. As a result, 
the "objective reality" is less relevant in human life than the "perception of reality" (Papadopoulos, 1993). This is why exceptional importance has been given to the "creation" of image in the past years - of a desirable picture in public which is often far from reality, but people, nevertheless, believe in it. According to Boorstin (2000), image can be more or less successfully produced, improved, polished, renewed, refreshed.

This is why the central topic of this paper is the role of image and the mutual perception of Croatia and the European Union on the one hand and the effects of this perception on their mutual relations in the process of Croatia's accession to that community on the other. It can be presumed that the image of the European Union, its institutions and the most influential member-states was among the Croatian public determined by the relation of Croatian citizens, i.e. the level of support toward the entrance of Croatia into this community. Likewise, it is indisputable that the level of recognition and the image of Croatia largely affected its political destiny in international relations - from international recognition after the collapse of Yugoslavia to full EU membership. For this reason, this paper deals with the mutual perception and role of image in mutual relations between Croatia and the European Union, and will attempt to show their causes and consequences.

During the past twenty-five years, the image of the European Union in the eyes of Croatian citizens, as well as the image of Croatia from the perspective of the European Union, that is, other member countries, has changed somewhat as a result of diverse formal and informal reasons. Furthermore, in order to better understand the complex and emotionally laden relations between Zagreb and Brussels in the past twenty-five years, and thereby the foundations of the present image, it is necessary to return far into the past.

In this overview we will outline the historical and political context of the mutual relations, together with the context of the creation of Croatia's image - a rarely analyzed subject - and present all the relevant research on the mutual perception, including an original survey on the perception of the European Union in the country. As Croatia is a relatively new nation, not many surveys have been carried out in it so far and the accession negotiation process is a specific context enabling us to understand the importance of mutual perception and its effects on concrete political decisions. 


\section{Perception of "historical belonging to Europe" and the long road to EU membership: The historical and political context of relations}

The fate of Croatia and European countries has been inextricably and permanently linked for centuries. Ever since Croatia was recognized for the first time as a state by Pope John VIII on July 7, 879, it shares the adversity and contributes to the European continent in various areas - from culture, architecture, arts and science to joint military campaigns. ${ }^{1}$ As a reminder, in 1102 Croatia established a personal union with Hungary, accepting the Hungarian king as its own ruler. The larger part of the Croatian coast (with the exception of the Republic of Dubrovnik, which developed independently from 1358) was ruled by Venice for centuries. After the Ottomans invaded in the $16^{\text {th }}$ century, resulting in the loss of large parts of the country, Croatian feudal lords elected Ferdinand I of the Habsburgs as ruler, whereby Croatia became a part of the Austrian Empire, of which it would remain until 1918. Numerous important Croatian figures were active in European capitals, providing exceptional contributions to European science and arts, and Croatian culture is an integral part of Europe's greatest cultural achievements - from the Middle Ages, the Renaissance and the Baroque to the Modern. Actually, its culture, as an integral part of Western culture, is Europe's most prominent arm toward the southeast. ${ }^{2}$

With the disintegration of the Austro-Hungarian Empire in 1918, Croatia became part of the Kingdom of Yugoslavia, and then a republic in Socialist Yugoslavia (1945). At the end

1 Croats are extremely proud of their early relations with the Pope and the Vatican, since they joined the Western European cultural circle with the acceptance of Christianity. Pope John Paul II kept reminding us of this fact, emphasizing that the Croats were the first Slavic nation to adopt Christianity. In his address to Croatian pilgrims gathered in the Vatican on May 15, 1978 he said: "There is no doubt, the bold act by which Prince Branimir, during the times of the schism between the Eastern and Western Church from the Byzantine Empire, wholeheartedly went over to Rome and the West, made the reality of Croatia Christian” (Nagy, 2011, p. 54). And in his written message directed to the Croatian believers gathered at the church celebration in Marija Bistrica on September 8, 1981 he wrote: "By accepting baptism and confessing the only apostolic, Roman Catholic faith, Croats also established a rapport with the Western Roman culture, and in this way they became an integral part of the Christian nations of Europe, which in that very moment formed into a spiritual and cultural community...” (Petrač, Šanjek 1995, p. 36). Pope Benedict XVI, during his visit to Zagreb on June 4, 2011, said in his address: "From the very beginnings, your nation belongs to Europe and it, in a special way, gives a contribution to it, in spiritual and moral values, which over the centuries have formed everyday life, as well as the personal and national identity of its children."

2 The Croatian Academy of Sciences and Arts launched in the mid-1990s a large publication "Croatia and Europe" within the framework of which five volumes were published, which through different historical periods and fields of action describe and analyze, in a comprehensive and systematic way, the connectedness and saturation of the Croatian culture, arts and science with the European context, i.e. Croatian contributions to Europe. The first volume Early Period of Croatian Culture (600s - 1100s) was published in 1997. It was followed by: Middle Ages and Renaissance (1200s - 1500s), Baroque and Enlightenment (1600s - 1700s), Modern Croatian Culture (1800s) and Contemporary Croatian Culture (1900s). It is an extremely valuable scientific source for the Croatia's entire history and culture within the European context, from its very beginnings to this very day. 
of the 1980s, part of the political elite strove for the dissolution of Yugoslavia, because they considered this as an opportunity to escape from the domination of Serbia in the Yugoslav federal association, for Croatia's long-awaited independence and for a return to "circles of Western civilization". In their aspirations, they counted on the support of the institutions of the European Community, i.e. the countries with which they were connected by common history and culture. These expectations were supported by the fact that Croatia had been economically the most developed and advanced republic of the former Yugoslavia, with traditional historical, cultural and religious links with Central and Western Europe (Čehulić, 2000, p. 66). This was particularly evident at the beginning of the 1990s, during the breakup of Yugoslavia and the beginning of war in Croatia and Bosnia and Herzegovina. At that moment, the eyes of the Croatian people were set on Europe with the logical expectation of protection, recognition of autonomy and independence. Apart from the statements of political officials, the European Community flags waving picturesquely on Croatian squares, as well as Croatian intellectuals calling on the support of European politicians, bore witness to this. However, the Europe that Croatia relied upon was obviously taken aback by the outbreak of aggression in multinational Yugoslavia and was clueless on what position to take regarding the republics that wanted to become new countries on the map of Europe. On this topic of reliance on Europe, in 1991, Pavao Novosel (1991, p. 25) stated that the processes that followed put an end to Croatia's romantic relationship toward the West.

"It was a world of illusions where Croats, in terms of geographic location, history, contribution to world culture, civility, national character, considered themselves an uncontested part of Europe, although Croats themselves were aware that they were a 'minor' partner of this larger civilization (although there are no real historically based reasons for such an opinion). However, even in such a modest definition, Croats saw themselves as a nation that Europe accepts and acknowledges in this role, if not like an equal to themselves then at least as a poorer first cousin.” (Novosel, 1991, p. 25)

Novosel adds that aggression on Croatia was a kind of "return to reality". Namely, Europe (from which "help was expected to come") remained idly watching the destruction and killing, giving "lectures” and doubting Croatia's ability to survive as an independent 
country. "Therefore, we can freely say that this Europe, whose integral part we believe we belong to, left us in the lurch. Truth be told, it must be emphasized that not all member of the European Community behaved equally." (Novosel, 1991, p. 25) However, Novosel adds that it was precisely this "sobering" that positively affected Croatia's "self-defining", i.e. that prompted the Croatian people to begin to learn "who and what we are, and what kind of place belongs to us in this new world”. Stanko Lasić (1992, p. 15) wrote similarly about the role of the various European institutions:

"For us, Europe was a symbol of freedom, democracy and the right of a nation to sovereignty, therefore, our natural ally, in whose arms we rushed, and it looked at us with astonished eyes and even somewhat scornfully smirked at our desire to constitute ourselves as a historical subject. With determination we insisted we did not want to see this face of Europe, even relying on it as our only ally. Fortunately, events evolved in such a manner that we did not pay a price that was too high for our illusion. We gained precious experience and it would be fatal to once again forget it.”

Alain Finkielkraut (1992, p. 27) finds the reasons for such relations of European institutions toward Croatia in the fact that Europe was not at all familiar with Croatian history, and that, for her, Yugoslavia itself was an old enough nation.

"The intellectuals and political leaders who talk about the Croatian people as though they were a 'tribe' thus show their profound historical ignorance; an ignorance that the form taken by the war should have dispelled, if only they had eyes with which to see. Serb aggression was aimed not only at the industrial and military power of Croatia. While the European elite was worried about Croatians' 'tribalism', Europe was losing in Croatia its Baroque and Roman churches, as well as its Venetian palaces.” (Finkielkraut, 1992, p. 27)

Similar to this is the plea by ten French intellectuals, led by the famous writer Eugene Ionesco. Deeply worried about the war destruction in Croatia, on December 6, 1991, they addressed the presidents of European countries, demanding the recognition of Croatia's independence. In this plea, they emphasized that "Europe has allowed Vukovar to suffer yesterday, Osijek today and Dubrovnik tomorrow", and demanded from European politicians 
not to "celebrate over the bodies of the dead", and instead of going on a "safe journey" to Maastricht, to rather visit besieged Dubrovnik (Croatian Information Centre, 1998, p. 68). As a reminder, the leaders of twelve European Community members, at a meeting in Luxembourg on June 23,1991, agreed not to recognize the independence of Slovenia and Croatia if these two republics decide unilaterally to leave the Yugoslav federation (Večernji list, June 23, 1991). Only after a series of attacks on Croatian cities did the European parliament on September 21, 1991 first "recognize the right" to self-determination and secession of republics of the former Yugoslavia, and called on its member-countries to consider the possibility of recognizing the republics that declared independence (Croatian Information Centre, 1998, p. 95). And the recognition of an independent Croatia by most European countries followed only at the beginning of 1992.

Marko Goluža (2001, p. 479) claims that "Croatia entered its independence with two major misconceptions. Firstly, we thought that Europe knew about us as much as we wanted it to know because we thought of ourselves as belonging to Western civilization and culture. And because it knew, it would automatically protect us. We were disappointed in both aspects!" However, despite the disappointment with the procedures of the European institutions, "Croatia's belonging to Europe" remained a permanent constant in the discourse of Croatian politicians for the past two decades. With an examination into Croatian literature from the last fifteen years, we can notice the emphasis on a regular basis of Croatia's belonging to the "advanced" Western European civilization, as a sort of justification or to highlight differences in relation to other countries in the Balkans. However, it can be assumed that “Croatia’s failed return to Europe” in 1991, i.e. Europe's disorientation during the conflict in the former Yugoslavia had an effect on the contemporary perception of the European Union. This would especially come to the fore during the accession negotiations, when Croatian citizens began to view the European Union and its role in the life of Croatia much more critically.

Relations between Croatia and the European Union began to develop with the international recognition of Croatia as an independent and sovereign state. However, because of the political climate in Croatia (Ott, 2006), they would only intensify in the late 1990s with the change of government. Namely, immediately after the international recognition of Croatia in 1992, which returned a glimmer of hope and confidence in Europe as a "protector 
of the young Croatian state", Croatian officials publicly expressed their commitment to full membership in the European Union. But first the war and then the slowing down of democratic progress, that is, objections of the international community over the slow taking root of democracy in the country, prolonged Croatia's wait for a European future. Only with the change of government in early 2000 was there a shift from the authoritarian form of government, leading to an institutional rapprochement of Croatia with the European Union. Thus, in 2003, after Slovenia, Croatia became the first country of the former Yugoslavia to begin the European Union accession process. However, negotiations on Croatia's accession to the EU did not start smoothly. A particular problem was the lack of cooperation with the War Crimes Tribunal in The Hague (ICTY). The most important point of the cooperation was locating, arresting and extraditing fugitive general Ante Gotovina, who led Operation Storm in 1995 to liberate the country, and who was on the run since 2002. He was arrested in $2005^{3}$, which enabled the beginning of negotiations. The long and often exhausting negotiations between Croatian and the EU enjoyed the support of all of the political elite. They were additionally slowed in 2007, with the blockade by neighboring Slovenia over unresolved border issues and the succession of former Ljubljanska Banka. After an agreement was reached between Slovenia and Croatia on contentious issues, negotiations were completed in December 2011 with the signing of the Accession Treaty. Croatia then conducted a referendum among its citizens on Croatia's accession to the EU in January 2012 and on July 1, 2013, Croatia became the $28^{\text {th }}$ full member of the European Union. $43.51 \%$ of voters took part in the referendum, 66.27\% of the population voted for Croatia's accession to the EU, and 33.13\% voted against. The lower turnout at polls and the significant number of citizens who voted 'no' can be interpreted with three assumptions - fatigue with long-lasting negotiations and a disinterestedness among part of the citizens, lack of quality debate among the Croatian public on the advantages and disadvantages of Croatian membership in the EU and a peculiar boycott against the government, which overtly promoted exclusively the advantages of the membership and did not tolerate Eurosceptic views.

3 Found not guilty and freed in 2012 . 


\section{Yugoslav propaganda, neutralizing the stereotype and building the image of Croatia in the European Union}

Although Croats have a relatively long tradition as a nation, due to 70 years of living in two Yugoslav states (1918-1940,1945-1990), and to strong Yugoslav propaganda in international relations dominated by Serbs, Croatia has been largely unknown and tied to negative stereotypes. For example, in 1990, only 267 (11.8\%) of the 2.256 employed in the Federal Secretariat of Foreign Affairs (Yugoslavia's Ministry of Foreign Affairs), were from Croatia. Furthermore, the individual republics, including Croatia, could not influence who from its ranks would be appointed ambassador or consul, nor did they have the right to recommend their appointment. Furthermore, although Croatia generated $80 \%$ of Yugoslavia's tourist traffic at the time, it had its representatives in only four Yugoslav representative offices throughout the world (Croatian Information Centre, Zagreb, 1998, p. 29).

For this reason, even tourists who vacationed for years in Dubrovnik associated this city not with Croatia but only with Yugoslavia. Because of the openness of Yugoslavia toward the West, some particular areas had become popular, cheap summer resorts in Europe, especially those on the beautiful Adriatic coast in Croatia. But only a small number of tourists spent their free time finding out anything about this country and its people (Brkić, 1994, p. 178).

"The former Yugoslavia did not allow too much autonomy for its republics in international activities. International contacts were held at the federal level. All international connections were carried out through Belgrade, and not only embassies, representatives of international organizations, but also almost all accredited journalists were situated in Belgrade, for which the authorities provided very well. The notion they had about the republics of the former Yugoslavia was highly influenced by Belgrade. The overall foreign policy was implemented from Belgrade, so thereby the role of journalism was clearly directed. The overall former diplomatic and newspaper machinery was more than active in the creation of a completely distorted image of the social system, politics and nations of the former Yugoslavia. The official propaganda was intentionally silent on the national values of all nations, with the exception of the Serbian nation, and the image of Croats 
as a genocidal nation was systematically created. In Western countries, under the aegis of embassies, strong pro-Serbian lobbies actively operated. Milošević's regime noticed in time the significance of creating a good image in the world, so the international edition of Politika was launched in the English language (and Politika was an extreme advocate of the idea of Greater Serbia)." (Malović, 1993, p. 33)

In the beginning of the war, Croatia was perceived in Britain - according to research by Chris Cviić (1994, p. 153) - as a "usual suspect" for the disappointment and failures of the West itself regarding the collapse of Yugoslavia. Cviić argues that Britain, as well as other Western countries, blame Croatia for the demise of their child - Yugoslavia, instead of realizing that neither Croatia nor Slovenia was to blame for this child, but rather Milošević's Serbia.

Tom Cushman ${ }^{4}$ argues that, because of stereotypes and prejudices, which have created a negative image for Croats, the West in the early 1990s frequently did not perceive Croatia as a victim of war, as they considered, for instance, Bosnia and Herzegovina.

"By neglecting the huge contribution and struggle of Croatian anti-fascists, and the Croatian anti-fascist movement was relatively the largest in Europe, Belgrade has distorted the facts and labelled all Croats and all of Croatia for Pavelićs criminal, quisling regime and the war alliance between the Independent State of Croatia and Hitler's Germany. By spreading the idea of collective guilt for the whole nation, Belgrade justified the aggression and the killing of thousands of Croats who were executed in the post-war period, without trial, by Communist power-holders." (Sanader, 2000, p. 27)

Blaskovich (1998, p. 135) argues that the new Croatian state has made a multitude of mistakes in international relations with the public and the fight against Serbian propaganda because, during the Yugoslav communist era, Serbs pulled the strings of the political development and public relations with other Yugoslav nations. In addition, Croatia was unable to find help for the realization of its objectives because it lacked an adequate administrative body, which could fight the sophisticated Serbian propaganda machine. In the beginning of the war, the only relevant source of information from the area of the former Yugoslavia was the Yugoslav news agency - TANJUG, which was usually quoted by world agencies, despite their

4 Interview for Voice of America, www.voa.gov/miscl/croatia/cush.html, June 14, 2002. 
lies. HINA (Croatian News Agency) did not manage to earn the trust of foreign journalists and this agency was viewed distrustfully.

This is additionally confirmed by the fact that the former Yugoslavia had a relatively positive image in the international community and was already developing a recognizable country brand. This positive image played an important role in covering the undemocratic nature of the political regime in the former Yugoslavia and consequently blurred the insights of the international community into the causes of disintegration of Yugoslavia and eventual causes of inevitable war (Miličević, Skoko, Krešić, 2013, p. 238).

Because the ex-Yugoslavia was the founder and an important member of the Non-Alignment Movement, and because it developed a special Yugoslav model of socialist system, western countries perceived it, not only as the bridge between East and West, but also as a bridge between North and South. In this context, it is also important to call to mind the role that the lifetime president of Yugoslavia, Josip Broz Tito, played in the international community. In his decades in power, as one of the founders of the Non-Aligned Movement, he played an active role in international politics, and with his specific socialist system - so-called socialism with a human face, he gained many supporters and had a very positive image in the western countries which was, however, substantially different from reality (Sanader, 2000).

So in the early 1990s, as a new sovereign state on the map of Europe, Croatia faced two major problems. In a relatively short period of time, it had to position itself on the international political stage and win the favor of the international community, while at the same time defending its territory in an imposed war. In such circumstances, it is extremely difficult to create recognizability with the European public and take care about image. The outbreak of the war drew global attention and Croatia was largely perceived as a victim of aggression. However, arising at the same time was a multitude of misinformation, prejudices, stereotypes, disorientation and even the results of propaganda activities, which further complicated understanding of the situation in the former Yugoslavia, as well as the relationships between individual nations and the former republics. Thanks to the decision by citizens in a referendum on Croatia's independence (an astounding $94.17 \%$ of Croatian citizens supported leaving the Socialist Federal Republic of Yugoslavia), the presenting of the truth about the events in the former Yugoslavia and strong lobbying activities, Croatia managed to secure international recognition from the majority of European countries in January 1992. Subsequently, international 
communication was somewhat facilitated for Croatian institutions.

In order to emphasize its differentiation compared to other former Yugoslav republics, Croatia began its strong international tourism promotion even while Croatia's Homeland Defense War was going on in 1994. Highlighted is its natural beauty, the Adriatic Sea with its thousand islands and its rich cultural and historical heritage, as well as long tourist tradition, by which it emphasized its uniqueness and advantages in relation to its neighbors. Diverted in this manner was a part of the attention on the war, which awakens for the most part negative associations, regardless of compassion. After the end of the Homeland Defense War and the liberation of occupied territories, Croatia, with its natural advantages and cultural wealth, invested additional efforts in promotion and development of tourism, which positioned it as one of the leading tourist destinations in the Mediterranean.

During the last two decades, Croatia has successfully repositioned its image, from newly formed Balkan state, burdened with the legacy of war, conflict and socialism - to a beautiful and attractive Mediterranean tourist destination. Although in the public domain of some countries (especially countries in northern Europe), Croatia is still somewhat associated with the war and the legacy of former Yugoslavia, this perception has substantially changed over the past two decades (Miličević, Skoko, Krešić, 2013, p. 236).

In the meantime, Croatia had not provided many occasions for the European public to take an interest in it. The topics that dominated the European institutions and the media regarding Croatia were mostly related to democratic standards and development of democracy, economic development, war crimes trials, the attitude toward Serb refugees from Croatia, generally, the normalization of relations in the region. Meanwhile, Croatia has achieved a number of significant sporting successes, which further promoted it in the eyes of sports fans as a sporting nation. Leaving a particular mark was Croatia's football success at the World Cup in France 1998 when it finished in third place, with Croatian footballer Davor Šuker winning the Golden Boot award as the tournament's top goal scorer. Unfortunately, Croatia did not take advantage of the opportunity to present itself, after the war, to Europe and the world as an economic, cultural or scientific entity, although it possessed all of the necessary qualities in these areas compared to countries in its surrounding.

Tourism promotion has significantly helped Croatia to position itself as an attractive tourism 
brand but, at the same time, the major strengths of Croatian tourism, communicated through tourism promotion activities, overshadowed all other Croatian comparative advantages and, today, Croatia is generally recognized as a successful and beautiful "sun and sea" tourist destination. Tourism has undoubtedly had a significant influence on building the contemporary brand of Croatia as a country, but Croatia still has to undertake additional efforts to position itself as a new member of the European Union, as well as an important political and economic entity in this part of Europe (Miličević, Skoko, Krešić, 2013, p. 237). Interest in Croatia as a political and economic entity increased in the European media first of all with the start and then with the intensifying of negotiations on accession to the European Union, i.e. after 2000 and 2003.

In the last decade Croatia was characterized by political and, to a certain extent, economic stability, which contributed to the image of Croatia as a free and democratic country in a very volatile and politically unstable Balkan region. ${ }^{5}$ The further political and economic destabilization of an already politically and economically unstable region has helped Croatia to present itself as a stable democratic country in Southeastern Europe but also as an attractive tourist destination and as a country with the nearest access to the warm Adriatic Sea for many Central European countries. A great contribution to the tourism positioning of Croatia has also come from the construction of a quality network of new highways, which connected Croatia with many important tourism generating markets.

\section{How do Croats perceive the European Union?}

In the introductory part of this paper, there was word on the perception of the European Union as a potential "savior" of Croatia at the beginning of aggression and the war in the former Yugoslavia, betrayed expectations, as well as change in the perception of the European Union in the eyes of Croats during the 1990s. For this reason, the focus in this part will be on the image of the European Union in the Croatian public, after the start of institutional relations between the Government of the Republic of Croatia and the EU Commission in

5 For instance, during her visit to Zagreb on October 31, 2012, U.S. Secretary of State Hillary Clinton stated: "You have decided to be a part of a peaceful and free Europe and Transatlantic community, you have served as an anchor within the region, a prosperous country which can be model for others. (...) You are an excellent country for investments; you have a splendid geographic position and educated workforce. But we support you to cut down on bureaucracy, continue with the process of privatization and facilitate the opening of new firms." 
2000. The warming of relations between Zagreb and Brussels had a positive effect among Croatian citizens, and the opening and start of negotiations on Croatia's accession to the EU was followed by a positive perception of the EU. Bearing witness to this are various Croatian public opinion polls and preference ratings for Croatia's accession to the EU. The agency GfK, which measured the preference of Croatian citizens for accession to the EU, marked the record support of $77.6 \%$ of the population in December 2000 for Croatia's accession to the EU. After this, support was largely consistent for the next three years, only to undergo a drastic drop in 2004, which has continued since then.

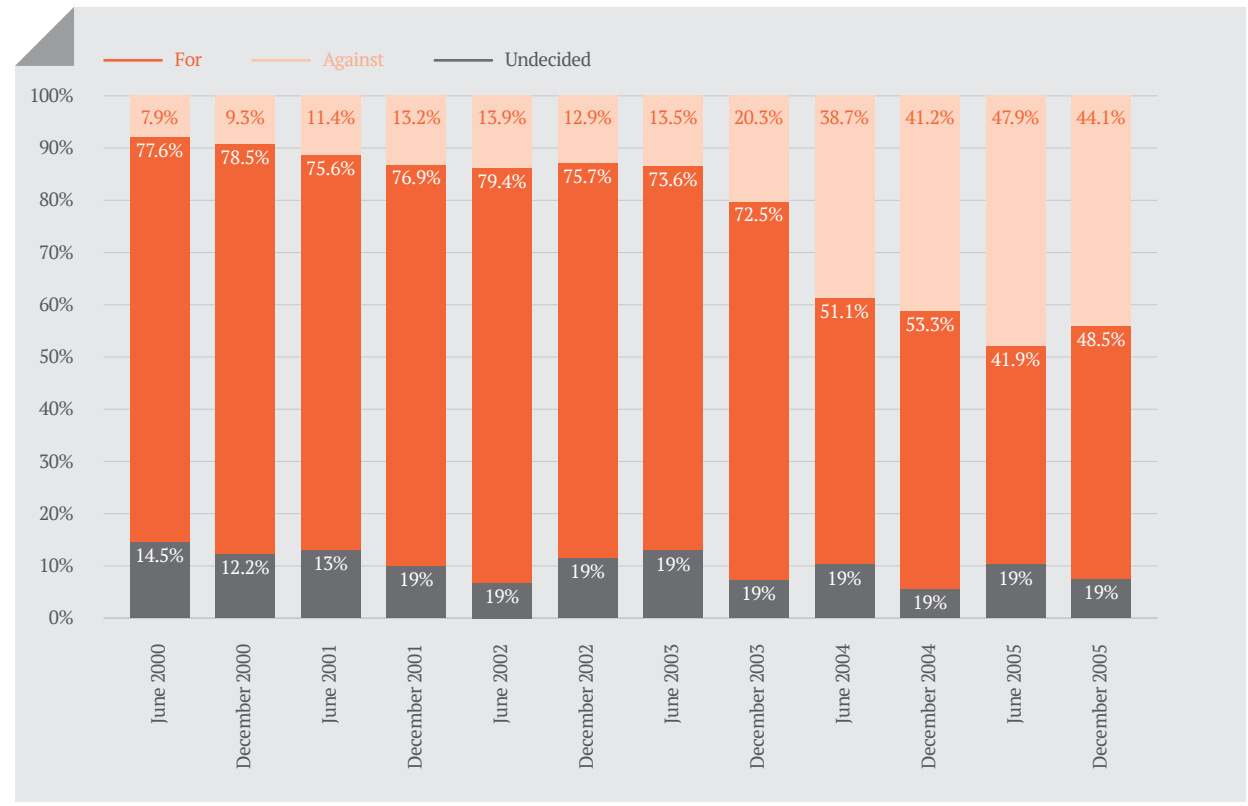

Figure 1. Inclination of citizens for Croatia's accession to the European Union in the 2000-2005 period

Source: Ministry of Foreign Affairs of the Republic Croatia; www.mvpei.hr/ei/ May 15, 2010, the survey was conducted by the agency GfK in the $2000-2005$ period, $\mathrm{N}=1.000$

As a reminder, in 2003, there was a change in the governing coalition in Croatia, i.e. the return to power of the Croatian Democratic Union (HDZ). Although the new government, led by Prime Minister Ivo Sanader, intensively continued with pro-European policies, and in some areas was even more susceptible to the requirements of Brussels than the previous social democratic government, the decline in support for the European Union from one year to the 
next was unstoppable until the beginning of the campaign for the referendum on accession, which managed to stop this trend. The reasons for this can be found in the more energetic approach of the Croatian Government toward the European Union, and greater concessions to and pressure from Brussels, especially in regard to the extradition of Croatian general Ante Gotovina, indicted for war crimes (Skoko, 2007, p. 356).

However, in order to determine the real reasons for these changes and explore the perception of the European Union in Croatia, we conducted a survey using the focus group method ${ }^{6}$ (Skoko, Bagić, 2011). A specific objective for us was to discover the motives, reasons and arguments by which Croatian citizens "justified” their negative attitude toward full Croatian membership in the EU. However, here we will present only the image of the European Union and its relations toward Croatia from the perspective of Croatian citizens, which this study revealed.

The negative perception of the European Union was based on a number of impressions. Among them, the most common was the unfair treatment of Croatia during the accession process. Namely, strongly present among participants of the focus groups was the impression that the European Union failed to approach Croatia's accession process in good faith, and that this approach toward Croatia was not the same as was the case for other potential EU members, and this in various stages of the accession process. It is possible to identify three different aspects to this argument. The first consists of the feeling that Croatia was treated unjustly since some other new member states joined the EU before Croatia (Bulgaria, Romania, Slovenia, Hungary etc.). Behind this point of view is the implicit or explicit assumption that these member states were no more developed and prepared for accession to the EU than Croatia at the time. Indeed, there was a strong feeling that Croatia was, in terms of development, considerably more advanced than some of these new members (this refers primarily to Romania and Bulgaria). In favor of such a perception are the following facts: GDP per capita in EUR in 2007 was as follows: Croatia 10,100, Bulgaria 4,000, and Romania 6,400 (source: Eurostat). The rating of countries according to the Business Competitiveness Index for $2007-2008^{7}$ : Croatia 60, Bulgaria 83, and Romania 73. The Media Freedom Index (according to Reporters without Borders ${ }^{8}$ - the lower the index, the better): Croatia 12.5, Bulgaria 16.25 and Romania 12.75. Such injustice

6 There were three focus groups, each with 12 respondents. The respondents came from various age and social groups of Croatian society and had various levels of education.

7 Retrieved from http://www.poslovni.hr/mobile/hrvatska/na-svjetskoj-listi-konkurentnosti-hrvatska-napredovala-za-samo-dvamjesta-59210, May 25, 2014

8 Retrieved from http://www.rsf.org/IMG/pdf/index_2007_en.pdf, April 17, 2014 
is explained by the different political criteria used in making decisions about membership, i.e. the fact that, for membership, the level of development of a country is not sufficient, and other political arguments are also used.

"Related to this is the second aspect of unfair treatment, which basically refers to regional or group accession to expansion in the Western Balkans, which certain European politicians promoted. Some participants felt that the EU deliberately delayed Croatia's accession so that all the countries of the former Yugoslavia could join together. Behind both of the previous points is the belief that a decision on membership was based on the arbitrary political decisions of the 'great powers' rather than on an objective assessment of the readiness and development of a specific country." (Skoko, Bagić, 2011, pp. 59-60)

The third aspect of this argument suggests that the requirements that were put before Croatia were constantly being changed. The changing of criteria was perceived as blackmail and as malevolent and hostile behavior by the EU. Some respondents expected that accession be implemented in such a manner that the EU actively "assists" members to adapt, and not to "blackmail" them, as the setting of requirements and expectations from candidate countries to fulfill these requirements was interpreted (Skoko, Bagić, 2011, pp. 60-61). As a reminder, Croatia underwent the longest negotiation process of all member countries of the European Union. It is interesting that, once again, this survey confirmed the theory of Europe's betrayal in the 1990s, and evoked feelings of rejection. Namely, respondents insisted on the thesis that "the EU (EEC at the time) and its most prominent members were not playing a (sufficiently) positive role at the beginning of the war, when Croatia was threatened by 'Serbian aggression'”. The scope of positions ranged from condemnation for inaction, i.e. lack of involvement in the events in the former Yugoslavia, to charges of advocating solutions that were contrary to the interests of Croatia - this being the preservation of Yugoslavia. Of course, this argument is not only based on an assessment of the activities of official bodies of the EU (EEC at the time), but largely also on the activities of the most prominent countries. (Skoko, Bagić, 2011, p. 63). Similar results were also received in the survey on the perception of the European Union in the Croatian public from 2006. At that time, an astounding $52 \%$ of respondents felt that the EU was trying to equalize the role of Croatia and Serbia in the war, and 50\% that the EU was responsible for violating the dignity of the Homeland Defense War. A similar percentage of 
respondents stated that they "had the feeling that the EU was pushing Croatia back into the Balkans" (Skoko, 2007, p. 360).

Otherwise, the perception of the EU was strongly marked by internal disorder and lack of vision. In fact, respondents believed that the EU itself was not stable and organized internally, which could even potentially result in a breakdown of the EU itself. Emphasized as an argument was the fact that members could not come to an agreement on several important issues. Used to confirm the thesis about the difficulty in coming to agreement and the absence of internal "discipline" was the Slovenian-Croatian border dispute, which was the reason why Slovenia for a certain period of time blocked Croatia's negotiations with the EU.

"In the opinion of some of the respondents, the EU did not take the side of Slovenia; however, there was no internal mechanism in place to force Slovenia to take a different (more correct) course of action. The inability to reach agreement was the outcome of the lack of a common identity and the dominance of powerful 'nationalism', which is why the EU will never be able to 'attain the US'. Another argument for the lack of organization of the EU is internal disputes about the 'limited pie' and excessive 'bureaucracy' of institutions when making decisions." (Skoko, 2007, p. 75).

The impression of inequality of EU members was also strongly present in Croatia. "The argument was based on the theory that all members have equal status within the EU and have the same benefits of membership, which means that it has an interest and political dimension. Privileged status was attributed either to a specific level (England, Germany and France) or the category level, such as wealthy countries, large members and old members." (Skoko, Bagić, 2011, p. 76) Such a feeling was strongly associated with the perception of the European Union itself, which was perceived as a community of unequals, i.e. as a system of power in which there is a strong difference between the center and the peripheries, between those who are "rich and powerful" and those who are "small and weak", where the "rich and powerful" exploit "the small and weak" to become even richer and more powerful, i.e. the "small and weak" are needed as a market. It is this feeling exactly that links fear of economic exploitation with the perception of disorganization and inequality within the EU.

It is obvious that such a perception also affected the awareness of Croatian citizens, i.e. their 
insufficient knowledge of the functioning of the EU. Dragan Bagić and Ante Šalinović (2006, p. 160) determined that institutional attempts at informing Croatian citizens was reduced mainly to passive methods of communication, while the general public was not interested in topics such as the institutional organization of the EU etc. In this manner, dominant among the public were numerous stereotypes, or conclusions were drawn on the present and future of the EU on the basis of the superficial following of media reports.

As can be seen, the perception of the EU in Croatia is strongly and emotionally burdened with the perception of relations toward Croatia, not only during negotiations, but also since Croatia's independence. Also concrete facts are not in the foreground, but rather emotions and impressions. However, when it comes to positive characteristics and perceptions, there are many more rational elements. According to this survey, the most positive perceptions are linked to the European Union as an area where institutions function properly and the rule of law governs, i.e. efforts are being intensively conducted on reducing corruption in various spheres of society (Skoko, Bagić, 2011, p. 80). Related to this is the expectation of survey respondents that accession to the EU will substantially restrict room for self-will among political elites, and contribute to the better profiling of good politicians and a change in generation in politics. Also, some of the respondents perceived the EU as a community that promotes social policies and human rights, which provides significant opportunities for studying abroad or finding employment (which some consider as negative consequences for society due to brain drain, and others as a positive opportunity for the individual). In addition, open borders and the possibility of traveling with no administrative barriers are also stated as positive aspects of the EU (Skoko, Bagić, 2011, p. 80). In any case, the perception of the EU is strongly marked by the activities of its political institutions and the larger member states and their relation to Croatia.

The reasons for such a perception is somewhat explained by Marijana Grbeša’s research (2011) on reporting on the EU in the Croatian press from 2007 to 2011. Namely, thanks to the conducted analysis of media content, the author arrived to the conclusion that the media presentation of the European Union was mainly related to representatives of the political and administrative elite, and only a small percentage on the daily life of the average person, which emphasized the "stern image of the Union" (Grbeša, 2011, p. 131). Thus, the image of the EU conveyed by the Croatian press over the five years of negotiations remained mostly 
in the domain of administrative and political actors, bureaucratic issues and questioning the responsibility of Croatia's slow progress toward European integration, while a more "lively" image of the Union was present in Croatian newspapers only very modestly and sporadically (Grbeša, 2011, p. 132).

The manner of reporting in the Croatian media had changed only in the year of Croatia's EU accession in 2013, when Croatian editions abounded with special contributions on how the EU functioned, and presented all of the member states individually, the benefits they enjoyed from living within the EU, contributions to joint coexistence, etc. The opinion that the EU was not just a bureaucratic entity, but rather a community of different countries was dominant only just ahead of Croatia's accession to the EU.

\subsection{The Croatian public's perception of the EU on the eve of Croatia's accession in 2013}

This was confirmed by a field survey conducted for purposes of this paper in May 2013 at the level of all of Croatia, on a sample of 1.000 adult citizens (i.e. approx. a month before the official accession, when, as expected, the optimism of citizens was at a high level). Respondents first cited spontaneous associations that first come to mind at the mention of the European Union, and then by means of the offered descriptions of the European Union chose the ones that, in their opinion, best describe their experience of the European Union. The most dominant spontaneous associations, grouped by similar concepts and value significance, are as follows:

Brussels, united Europe, the euro, negotiations, membership, union of states, Manuel Barroso, Angela Merkel, Croatian membership, stars, Ode to Joy, the color blue and so on (neutral categories) - $41 \%$

Unity, cooperation, openness, community of advanced countries, erasing boundaries, travels, new opportunities, raising standards, progress, quality education, the fight against crime and corruption and so on (positive categories) - 34\%

Bureaucracy, crisis, blackmail, loss of sovereignty, exploitation, brain drain, competition, disintegration, injustice, etc. (negative category) - $25 \%$ 
Concerning the prevailing image of the European Union, which we explored by offering respondents seven descriptions that appeared in the Croatian media, dominant is the neutral category that the European Union is a "community of interests consisting of 28 European countries" (42.5\%). Selecting the positive description of the EU as "a community that promotes peace and prosperity on the European continent, as well as takes responsibility for economic and social development and the protection of human rights" were $34.1 \%$ of respondents, while the assertion that it is "a community through which individual states can more easily achieve and protect their interests and rights" was selected by $23.2 \%$ of respondents. At the same time, $26.4 \%$ of respondents opted for the negative description that the EU is a bureaucratic institution dominated by the interests of large countries, and nearly $20 \%$ of respondents believe that the EU is "a supranational organization that takes part of the sovereignty and the right to vote from countries", $8.6 \%$ of respondents believe that this community has lost its purpose and reason for being. It is important to note that the selection of multiple answers was possible.

Table 1: Prevailing image of the European Union in Croatia*, 2013 (N=1.000) \%

The European Union is:

Total

Community of interests consisting of 28 European countries

Community that promotes peace and prosperity on the European continent, as well as is responsible for economic and social development and the protection of human rights

Bureaucratic institution dominated by the interests of the biggest countries

Communities through which individual states can more easily achieve and protect their interests and rights

Supranational organization that takes part of the sovereignty from and the right to decide from states

Community without consensus and vision, which has lost its purpose and reason for being

One of the most powerful unions of states in the modern world

Other

*Possibility of multiple responses.

Thus, in 2013, Croats have assumed quite a positive perception of the European Union; however, they are also very aware of its shortcomings. It is evident that some biases, such as those that European institutions are dominated by the interests of large and powerful states, are continually present. Despite the crisis, lack of vision and often lack of consensus among 
member states, as well as negative experiences during the negotiations and so on, the majority of Croatian respondents still consider the EU as a quality framework for the development of Croatia and the European continent in general.

\section{Conclusion}

Perception and image have played a significant role in the relations of Croatian citizens toward the European Union. The support of Croatian citizens for Croatia's accession to this community largely depended on the perception of the EU among the Croatian public. It can be presumed that the decision-makers in the European Union, with all measurable indicators of its progress, were also not deprived of the impact of the image of Croatia on their relation toward Croatia. The Republic of Croatia has entered the European Union, after years of negotiations, during which it had to meet criteria that were not required by any previous member. On this road, it had to shatter many stereotypes that had existed in certain European centers of power toward countries from the Balkans. However, despite numerous reforms, raising democratic standards and political and economic development, these efforts were practically unnoticed among citizens of the old EU member states, i.e. among Croatia's new neighbors. In countries of the European Union, Croatia is primarily perceived as a beautiful and attractive tourist destination. In addition to being familiar with Croatia's unique natural features, in a section of the European public, still present was associating Croatia with the war and the legacy of the former Yugoslavia.

The reason for such a "unilateral" image of Croatia can be sought in the fact that, for two decades, Croatia strategically and continuously carried out tourism promotion in the world and is intensively working on strengthening its tourism. At the same time, it has ignored other forms of promotion and international public relations (except for sporadic projects for the promotion of culture, the economy and sporting achievements), and it has insufficiently used to its advantage the opportunity, during the accession negotiations, to communicate to Europe its other advantages. A specific missed opportunity occurred in the period ahead of Croatia's official accession to the EU on July 1, 2013, when Croatia was in the limelight of the European public as a new member country that was, after a long time, joining the Union on its own, without any other countries. Namely, as a new member, 
Croatia had aroused the interest not only of intellectual and political elites, but also of ordinary citizens, which is best evidenced by the number of published reports referring to Croatia in the European media, as well as the increased number of visits to Croatia. Instead of Croatia presenting itself to its European neighbors in a strategic, creative and pragmatic manner, highlighting the strengths and potentials by which it will enrich the EU, the communication of Croatian political institutions with the world (with the exception of a few successful projects in the area of culture, as was the Croatian festival in France - "Croatie, la voici" (September - December, 2012) was largely reactive and bureaucratic. In fact, due to the lack of pro-activity in relation to the media and international publics, on the eve of Croatia's accession, there appeared a number of critical media reports on Croatia's unpreparedness for the EU. Most of them focused on poor economic indicators, unemployment, the collapse of industry, the growth of poverty, as well as corruption and bureaucracy that were still present, instead of Croatia's efforts on the road toward full membership and the numerous benefits that Croatian membership brings the EU. As a member of the EU, Croatia has additional possibilities for better presenting itself to the citizens of Europe, however, membership itself, as well as the processes that follow and the greater interaction with other member states, will certainly contribute to becoming better acquainted with each other.

When it comes to the perception of the European Union on the part of Croatian citizens, it is apparent that there are two levels of observation - the EU as an institution and the EU as a community consisting of 28 different countries. The image of the EU as an institution is significantly more negative because of the feelings of rejection from 1991, dissatisfaction with the negotiation process and the impression derived from bureaucracy and the lack of consensus and vision.

Actually, to speak about the comparison of mutual perceptions of Croatia and the EU is a thankless task because Croatian citizens consider the EU as a single collective (dominated by joint institutions in Brussels and Strasbourg, and only then by the positions of influential members), while the image of Croatia from the perspective of the EU is based on the perception of individual states, which - in addition to the general impression - nevertheless differs from country to country. For this reason, it would be wise in future research to explore the image of individual member states among the citizens of Croatia. 


\section{Reference List}

- Anholt, S. (2007). Competitive Identity, The New Brand Management for Nations, Cities and Regions. New York: Palgrave Macmillan.

- Bagić, D., Šalinović, A. (2006). Analiza troškova i koristi kao čimbenik potpore građana ulasku Hrvatske u Europsku uniju. In: Ott, K. (Ed.), Pridruživanje Hrvatske Europskoj uniji: izazovi sudjelovanja. Zagreb: Institut za javne financije/Friedrich Ebert Stiftung.

- Blaskovich, J. (1998). Anatomija prijevare - Medijski rat za Hrvatsku. Zagreb: Moderna vremena.

- Brkić, B. (1994). Američki pogled na Hrvatsku: mitovi koji čine besmrtnim nesporazum o ulozi Hrvatske u raspadu Jugoslavije. In: Petlevski, S. (Ed.), Velika Europa i mali narodi. Zagreb: AGM.

- Cviić, K. (1994). Pogled izvana. Zagreb: Znanje.

- Čehulić, L. (2000). Razvoj međunarodnih studija u Hrvatskoj. Međunarodne studije, 1 (1), 65-82.

- Dinnie, K. (2008). Nation Branding - Concepts, Issues, Practice. Oxford: Butterworth-Heinemann - Elsevior.

- Eurostat (2016). Retrieved from http://appsso.eurostat.ec.europa.eu/nui/submitViewTableAction.do, May 10, 2014

- Finkielkraut, A. (1992). Kako se to može biti Hrvat?. Zagreb: Ceres.

- Goluža, M. (2001). Promidžba Hrvatske u svijetu. In: Bilić, M. Misli 21. stoljeća. Zagreb: Globus.

- Grbeša, M. (2011). Europska Unija u hrvatskome tisku od 2007. do 2011. In: Šiber, I. (Ed.), Hrvatska i Europa - strahovi i nade (pp. 120-137). Zagreb: Politička misao, Fakultet političkih znanosti, Sveučilište u Zagrebu.

- Jaffe, D. E.; Nebenzahl, D. I. (2006). Nation Image \& Competitive Advantage. Copenhagen: Business School Press.

- Kotler, P., Gertner, D. (2005). Country as brand, product and beyond: a place marketing and brand management perspective. In: Morgan, N., Pritchard, A., Pride, R. (Eds.), Destination Branding: Creating the Unique Destination Proposition (pp. 40-57). Oxford: Elsevier Butterworth-Heinemann.

- Kunczik, M. (1997). Images Nations and International Public Relations. Mahwah, New Jersey: Lawrence Erlbaum Associates Publishers.

- Lasić, S. (1992). Tri eseja o Evropi. Zagreb: Hrvatsko vijeće europskog pokreta.

- Malović, S. (1993). Image hrvatskih medija u svijetu, Ph.D. Thesis, Varaždin: Fakultet organizacije i informatike, Sveučilište u Zagrebu.

- Martin, I., Eroglu, S. (1993). Measuring a Multi-Dimensional Construct: Country Image. Journal of Business Research, 28, $191-210$.

- Miličević, K. Skoko, B. Krešić, D. (2012). The Power of Tourism in Creating a National Brand: The Case of Croatia. In: Richards, V. (Ed.), Destination Branding \& Marketing IV (pp. 236-247). Cardiff: Welsh Centre for Tourism Research and Cardiff Metropolitan University.

- Nagashima, A. (1970). A Comparison of Japanese and U.S. Attitudes Toward Foreign Products, Journal of Marketing Research, 34, 68-74.

- Nagy, B. (ed.) (2011). Papa Ivan Pavao II. govori Hrvatima, Zagreb: FDI.

- Novosel, P. (1991). Europa 92. i Hrvatska 91. In: Novinarstvo i Europa 92. Zagreb: Alinea.

- Nye, S. J. (2003). Paradox of American Power. New York: Oxford University Press.

- Ott, K. (ed.) (2006). Pridruživanje Hrvatske Europskoj uniji - Izazovi sudjelovanja, IV svezak. Zagreb: Institut za javne financije and Zaklada Friedrich Ebert Stiftung.

- Papadopoulos, N., Heslop, L. A. (1993). Product - Country Images - Impact and Role in International Marketing. New York, London, Norwood: International Business Press.

- Papadopoulos, N. (1993). What Product and Country Image Are and Are Not. In: Papadopoulos, N., Heslop, L. A. (Eds.), ProductCountry Images: Impact and Role in Interantional Marketing (pp. 3-38). New York, London, Norwood: International Business Press.

- Petrač, B., Šanjek, F. (Ed.) (1995). Ivan Pavao II. i Hrvati, Zagreb: Alfa.

- Sanader, I. (2000). Hrvatska u međunarodnim odnosima. Zagreb: Golden marketing.

- Skoko, B. (2007). Percepcija EU u hrvatskoj javnosti. Anali Hrvatskog politološkog društva 2006. (pp. 349-368). Zagreb: Hrvatsko politološko društvo.

- Skoko, B., Bagić, D. (2011). Pet uvjerenja i 29 razloga protiv. In: Šiber, I. (Ed.), Hrvatska i Europa - strahovi i nade (pp. 47-85). Zagreb: Fakultet političkih znanosti, Sveučilište u Zagrebu: Politička misao.

- Hrvatski informativni centar (1998). Kronologija rata, Hrvatska 1989. - 1998. Zagreb: Hrvatski informativni centar.

- Voice of America. Retrieved from www.voa.gov/miscl/croatia/cush.html, June 14, 2002. 


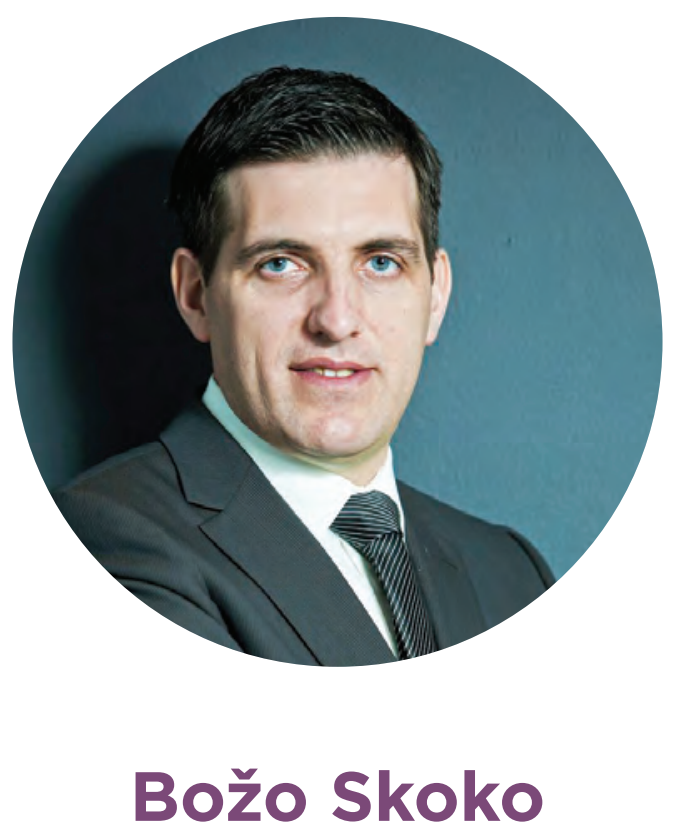

Božo Skoko, $\mathrm{PhD}$, is an associate professor at the Faculty of Political Science of the University of Zagreb, where he is head of the Public Relations and Journalism Department. The areas of his scientific research include: communication, international relations, national identity and image and branding destination. He is a long-time strategic communications consultant and co-founder of Millenium promocija, the leading Croatian public relations agency. He is a former journalist and editor at the Croatian Radiotelevision (HRT). He has published five books (Croatia and Its Neighbors - How Croatia Is Perceived in Bosnia and Herzegovina, Montenegro, Macedonia, Slovenia and Serbia (AGM, Zagreb, 2010); The State as a Brand (Matica hrvatska, Zagreb, 2009); Croatia - Identity, Image, Promotion (Školska knjiga, Zagreb, 2004 and 2005), as well as Handbook for Understanding Public Relations (MPR, Zagreb, 2006) and over forty scientific papers on public relations, the media and managing the identity and image of Croatia. 